\title{
Acceptability, continuation and satisfaction of postpartum intrauterine contraceptive device (PPIUCD) and delayed insertion: a comparative study
}

\author{
Neha Jain ${ }^{1 *}$, Nishat Akhtar² \\ ${ }^{1}$ Department of Obstetrics and Gynecology, AIIMS, Bhopal, Madhya Pradesh, India \\ ${ }^{2}$ Department of Obstetrics and Gynecology, Jawaharlal Nehru Medical College and Hospital, Aligarh Muslim \\ University, Aligarh, Uttar Pradesh
}

Received: 25 March 2017

Accepted: 27 April 2017

\section{*Correspondence:}

Dr. Neha Jain,

E-mail: nehanehajain1986@gmail.com

Copyright: ( ) the author(s), publisher and licensee Medip Academy. This is an open-access article distributed under the terms of the Creative Commons Attribution Non-Commercial License, which permits unrestricted non-commercial use, distribution, and reproduction in any medium, provided the original work is properly cited.

\section{ABSTRACT}

Background: Postpartum period is an ideal time to counsel and begin contraception as women are strongly motivated at this time, also being convenient for both patients and health-care providers. Copper $\mathrm{T} 380 \mathrm{~A}$ is a safe, highly effective method of contraception and has become the method of choice of many women for attaining their reproductive goals.

Methods: It was a prospective study conducted from February 2012 and November 2013 in the Department of Obstetrics and Gynecology, JNMCH, AMU, Aligarh, U.P.

Results: 386 clients were counseled for immediate postpartum IUCD insertion (GROUP-I), out of which $34.2 \%$ clients accepted for insertion but $24.3 \%$ actually got it inserted. 337 clients were counseled for extended IUCD insertion (GROUP-II) out of these $61.1 \%$ clients accepted but only $16.5 \%$ actually got it inserted. $10.63 \%, 6.02 \%$ and $5.19 \%$ clients in GROUP-I and 16.22\%, 13.11\%, 11.54\% GROUP-II went lost to follow up at 6 weeks, 3 months and 6 months respectively. Continuation rates in GROUP-I after 6 months was $73.4 \%$ in GROUP-I and 59.5\% in GROUP-II. Among the clients who continued, 92.7\% were satisfied in GROUP-I and $81.8 \%$ in GROUP-II.

Conclusions: Immediate postpartum IUCD has better acceptability, continuation and satisfaction profile when compared to extended insertion.

Keywords: Contraception, Extended insertion, Immediate PPIUCD, Postpartum

\section{INTRODUCTION}

More and more institutional deliveries in India makes immediate postpartum period the most precious time to counsel a woman for contraception, as the woman is highly motivated during early labour and immediate postpartum, also being convenient for both patients and health-care providers. ${ }^{1}$

The acceptance rate is highest during this period. The insertion of PPIUCD is easy than delayed one. Side effects of IUCD like pain and irregular bleeding get merges with the after pains and lochia of puerperium respectively which further increases the compliance. CopperT380A is a safe, highly effective method of contraception and has become the method of choice of many women for attaining their reproductive goals. ${ }^{2}$

Provision of IUCD in the National Population Policy 2000 is not a brand new concept but it has been there for a century from its primitive form to the latest modified form increasing its efficacy and decreasing infection risk. 
Govt. of India recommends Copper T380A Under National Population Policy 2000 as the IDEAL CONTRACEPTIVE having an efficacy of 12 years and pregnancy rate of $<1 \%$. $^{3}$

\section{METHODS}

It was a prospective study conducted from February 2012 and November 2013 in the department of obstetrics and gynaecology, JNMCH, AMU, Aligarh, U.P. after getting approval from the ethical committee.

Informed consent obtained and those clients eligible for PPIUCD insertion were included in the study.

\section{Inclusion criteria}

- Women willing for Copper T insertion and its follow up.

- Women meeting all the eligibility criteria for Post Partum IUCD Insertion.

\section{Exclusion criteria}

Women having

- Chorioamnionitis or Puerperal sepsis.

- $\quad$ Prolonged rupture of membranes of $>18 \mathrm{hrs}$

- Extensive genital trauma.

- Unresolved PPH

- Any abnormality of uterus or a large Fibroid distorting its cavity

- Pelvic Inflammatory Disease

- Malignant or benign Trophoblastic disease

- HIV/AIDS.

Clients were randomly selected from antenatal clinics and wards and were counseled for IUCD insertion. The clients who were counseled for immediate postpartum IUCD insertion (within $10 \mathrm{~min}$. of delivery of placenta) were assigned GROUP-I and those refused for immediate insertion but agreed for extended insertion (after 6 weeks to 1 year of delivery) were assigned GROUP-II. Those clients who actually got IUCD inserted were followed for acceptance and at 6 weeks, 3 months and 6 months interval they were followed for continuation and satisfaction and the results were compared.
40 new clients in the extended insertion group were added who reported to our family planning clinic by their own for IUCD insertion after 6 weeks of delivery.

\section{RESULTS}

Majority of the women in both the groups were younger than 30 years of age. Most of them were illiterate, Muslim by religion and housemaker.

Most of the clients were from the urban society. In immediate insertion group percentage of acceptance was only $34.2 \%$ but out of these $71.2 \%$ clients actually got it inserted.

In case of extended insertion group the acceptance was very high $(61.1 \%)$ but only $16.5 \%$ of them actually got it inserted.

Table 1: Sociodemographic characteristics of the cases in study.

\begin{tabular}{|c|c|c|c|c|}
\hline \multirow[b]{2}{*}{ Characteristics } & \multicolumn{4}{|c|}{$\begin{array}{l}\text { Total IUCD insertions } \\
(\mathrm{n}=168)\end{array}$} \\
\hline & \multicolumn{2}{|c|}{$\begin{array}{l}\text { Immediate } \\
\text { PPIUCD } \\
\text { insertion }(n=94) \\
\text { [GROUP-I] }\end{array}$} & \multicolumn{2}{|c|}{$\begin{array}{l}\text { Extended } \\
\text { post-partum } \\
(n=74) \\
\text { [GROUP-II] }\end{array}$} \\
\hline Age (in yrs.) & & $\%$ & & $\%$ \\
\hline $20-<25$ & 30 & 31.9 & 15 & 20.3 \\
\hline $25-<30$ & 43 & 45.7 & 43 & 58.1 \\
\hline $30-<35$ & 18 & 19.2 & 14 & 18.9 \\
\hline $35-40$ & 3 & 3.2 & 2 & 2.7 \\
\hline \multicolumn{5}{|c|}{ Educational status } \\
\hline Literate & 37 & 39.4 & 25 & 33.8 \\
\hline Illiterate & 57 & 60.6 & 49 & 66.2 \\
\hline \multicolumn{5}{|l|}{ Religion } \\
\hline Hindu & 24 & 25.5 & 15 & 20.3 \\
\hline Muslim & 70 & 74.5 & 59 & 79.7 \\
\hline \multicolumn{5}{|l|}{ Occupation } \\
\hline Housewife & 93 & 98.3 & 72 & 97.3 \\
\hline Employed & 1 & 1.7 & 2 & 2.7 \\
\hline \multicolumn{5}{|l|}{ Residence } \\
\hline Rural & 28 & $(29.8)$ & 16 & $(21.6)$ \\
\hline Urban & 66 & $(70.2)$ & 58 & $(78.4)$ \\
\hline
\end{tabular}

Table 2: Percentage of acceptability and actual insertion.

\begin{tabular}{|c|c|c|c|c|c|}
\hline Time of insertion & $\begin{array}{l}\text { Total no. of clients } \\
\text { counselled }(n=723)\end{array}$ & $\begin{array}{l}\text { verbally accepted } \\
\text { clients }(n=478)\end{array}$ & $\begin{array}{l}\% \text { of } \\
\text { acceptance }\end{array}$ & $\begin{array}{l}\text { Actual insertion } \\
(\mathrm{n}=213)\end{array}$ & $\begin{array}{l}\% \text { of actual } \\
\text { insertion }\end{array}$ \\
\hline $\begin{array}{l}\text { Within } 10 \text { min } \\
\text { Group-I }\end{array}$ & 386 & 132 & 34.2 & 94 & 71.2 \\
\hline $\begin{array}{l}\text { Extended post partum } \\
\text { Group-II }\end{array}$ & 337 & 206 & 61.1 & 34 & 16.5 \\
\hline
\end{tabular}


Table 3: Client selection of extended IUCD insertion group.

$\begin{array}{llllll}\begin{array}{l}\text { Total counseled } \\ \text { clients for extended } \\ \text { insertion }\end{array} & \begin{array}{l}\text { Verbal acceptance } \\ \text { for extended }\end{array} & \begin{array}{l}\text { Actual insertion } \\ \text { of extended } \\ \text { IUCD }\end{array} & \begin{array}{l}\% \text { of } \\ \text { actual }\end{array} & \text { New clients } & \begin{array}{l}\text { Total clients in } \\ \text { study in extended } \\ \text { insertion }\end{array}\end{array}$

Table 4: Distribution of clients according to the lost to follow up.

\begin{tabular}{|llllll|}
\hline & $\begin{array}{l}\text { Within 10 } \\
\text { min } \\
\text { Group-I } \\
n=19(\%)\end{array}$ & $\begin{array}{l}\text { Extended } \\
\text { Post partum } \\
\text { Group-II } \\
n=26(\%)\end{array}$ & $\begin{array}{l}\text { Total } \\
(\mathrm{n}=45) \\
(26.8 \%)\end{array}$ \\
\hline $\begin{array}{l}\text { Lost to 1 } \\
\text { follow up }\end{array}$ & 10 & $(10.6 \%)$ & 12 & $(40 \%)$ & 22 \\
\hline $\begin{array}{l}\text { Lost to 2 } \\
\text { follow up }\end{array}$ & 5 & $(6 \%)$ & 8 & $(40 \%)$ & 13 \\
\hline $\begin{array}{l}\text { Lost to 3 } \\
\text { follow up }\end{array}$ & 4 & $(5 \%)$ & 6 & $(42.9 \%)$ & 10 \\
\hline
\end{tabular}

Total of 337 clients were counseled for IUCD insertion in extended insertion group but only 34 (16.5\%) actually got it inserted. 40 new clients were added in this group who either reported by their own or were counseled by peripheral health care workers.

A total of 19 clients went lost to follow up in immediate insertion group and 26 patients in extended insertion group in total of 6 months follow up.

The continuation rate in the immediate insertion group after 6 months of follow up period was $73.4 \%$ which was only $59.5 \%$ in case of extended insertion group.

Table 5: Distribution of clients according to the continuation of IUCD.

\begin{tabular}{|c|c|c|c|c|c|c|}
\hline \multirow{2}{*}{ Follow up } & \multicolumn{3}{|c|}{ Within 10 min. GROUP-I (n=94) } & \multicolumn{3}{|c|}{ Extended insertion GROUP-II ( $\mathrm{n}=74)$} \\
\hline & Total clients & Continuation & $\%$ of (n) & Total clients & Continuation & $\%$ of (n) \\
\hline $1^{\text {st }}$ & 84 & 83 & 88.3 & 62 & 61 & 82.4 \\
\hline $2^{\text {nd }}$ & 78 & 77 & 81.9 & 53 & 52 & 70.3 \\
\hline $3^{\text {rd }}$ & 73 & 69 & 73.4 & 46 & 44 & 59.5 \\
\hline
\end{tabular}

Table 6: Distribution of clients according to their satisfaction.

\begin{tabular}{|c|c|c|c|c|c|c|c|}
\hline \multirow{2}{*}{\multicolumn{2}{|c|}{ Satisfaction }} & \multicolumn{3}{|c|}{ Within 10 min. Group-I (n=94) } & \multicolumn{3}{|c|}{ Extended insertion Group-II (n=74) } \\
\hline & & Total clients & Satisfaction & $\%$ & Total clients & Satisfaction & $\%$ \\
\hline \multirow{3}{*}{$\begin{array}{l}1^{\text {st }} \text { follow } \\
\text { up }\end{array}$} & Total & \multirow{3}{*}{ - } & 68 & 81.9 & \multirow{3}{*}{ - } & 40 & 65.6 \\
\hline & Partial & & 9 & 10.9 & & 10 & 16.4 \\
\hline & No & & 6 & 7.2 & & 11 & 18.0 \\
\hline \multirow{3}{*}{$\begin{array}{l}1^{\text {st }} \text { follow } \\
\text { up }\end{array}$} & Total & \multirow{3}{*}{77} & 70 & 90.9 & \multirow{3}{*}{52} & 41 & 78.8 \\
\hline & Partial & & 4 & 5.2 & & 7 & 13.5 \\
\hline & No & & 3 & 3.9 & & 4 & 7.7 \\
\hline \multirow{3}{*}{$\begin{array}{l}3^{\text {rd }} \\
\text { follow } \\
\text { up }\end{array}$} & Total & \multirow{3}{*}{69} & 64 & 92.7 & \multirow{3}{*}{44} & 36 & 81.8 \\
\hline & Partial & & 3 & 4.4 & & 4 & 9.1 \\
\hline & No & & 2 & 2.9 & & 4 & 9.1 \\
\hline
\end{tabular}

$92.7 \%$ of the clients who were still present in the study were totally satisfied after 6 months of follow up in immediate insertion group, while this figure was only $81.1 \%$ in extended insertion group.

\section{DISCUSSION}

Family planning counseling is still a major problem in India. The acceptability of long term methods is still low and continuation rates are even lower. Institutional deliveries provide better chance for contraceptive counseling to clients who are already motivated before and after delivery. Postpartum IUCD is the supposed to be the best method of long term contraception for parous women. It is an ideal method in spacing pregnancies. An effective counseling plays a major role in increasing the acceptance rate of PPIUCD. Continuation and satisfaction rate also depends on counseling. PPIUCD has lesser side effects when compared to the delayed insertion, which further increases the compliance. 
Fertility reverts quickly as soon as withdrawn and it is not at all impaired..$^{4-6}$ In contrast to OCP users, $75 \%$ women conceive within $6 \mathrm{mths}$ of IUCD withdrawal and $~ 95 \%$ conceive within $1 \mathrm{yr}^{7} 1^{\text {st }}$ and $2^{\text {nd }}$ generation IUCDs do not affect breast feeding but it is not same with OCPs. IUCDs are USE AND FORGET type of method for contraception thereby it is good choice for illiterate population, however in other type of barrier contraceptives continuous motivation is required thereby increasing the failure rate in inconsistent users.

In this study, total number of client counseled for post placental insertion were 386 out of which 132 (34.2\%) verbally accepted for PPIUCD insertion. Main reasons for refusal were side effects and various myths associated with PPIUCD. Out of 132 clients who verbally accepted for PPIUCD insertion in their antenatal period, 94 $(71.2 \%)$ clients actually got it inserted. Thus $24.4 \%$ of the total clients counseled actually got PPIUCD inserted. In second group 337 clients were counseled for IUCD insertion after 6 weeks of delivery out of which 206 $(61.1 \%)$ clients verbally accepted for IUCD insertion but the actual rate of insertion was quiet low i.e. 34 (16.5\%) clients. Although the acceptance was low in the early PPIUCD insertion group but most of the clients who accepted actually got it inserted. The reverse situation was seen in extended insertion group. The acceptance was high but the percentage of actual insertion was very low and this difference was highly significant ( $p$-value $=<0.001)$.

Our study was somewhat consistent with other studies conducted by Safwat et al, Ogburn et al and Chen et al. ${ }^{1,8,9}$ In the study conducted by Safwat et al, 3,541 clients were counseled, $1,024(28.9 \%)$ clients verbally accepted the use of IUCD, of these 264 clients were the verbal acceptors for PPIUCD insertion out of which 188 clients $(71.2 \%)$ had actual insertion of IUCD in immediate postpartum period. ${ }^{1} 750$ clients preferred interval/extended insertion but only 55 (7.2\%) had actual insertion. The acceptance was high in extended insertion/interval group but the rate of actual insertion was very high in case of immediate postpartum IUCD insertion than interval insertion. ${ }^{1}$ A retrospective study conducted on 1627 women by Ogburn et al, found that in case of failure to insert IUCD in the postpartum period, women often fail to return back and experience early unwanted pregnancy. ${ }^{8}$ Chen et al conducted a randomized trial, in which 51 women were enrolled to opt for post placental IUCD insertion out of which 50 women (98\%) had successful insertion, on the other hand 51 women were also enrolled to opt for IUCD insertion after 6-8 weeks, but 6 women were lost to follow up in 6-8 weeks thus, only 45 women $(88.2 \%)$ returned for insertion. ${ }^{9}$ Gujju RLB et al in their study found that out of 4209 clients counseled in their antenatal, early labour period and during cesarean section only 780 (18.53\%) clients accepted for PPIUCD insertion and actually got it inserted. ${ }^{10}$
According to the present study main reason of refusal was family refusal, fear of side effects and complication, desire of other family planning methods, satisfied with their previous family planning methods etc. The main reasons for refusal of clients who verbally accepted but refused at the time of insertion were family refusal and pain from delivery.

1 and 4 clients got IUCD removed in Group-I and 1 and2 clients in Group-II at $2^{\text {nd }}$ and $3^{\text {rd }}$ follow visit respectively. There was expulsion of IUCD in 1 client in each group at $1^{\text {st }}$ follow up visit.

In the present study, the number of women who continued the use of IUCD at 6 months of follow up was $69 / 94(73.4 \%)$ in post placental and $44 / 74(59.5 \%)$ in extended insertion group. Continuation rate of IUCD in immediate insertion group was higher than extended insertion group. The difference of continuation rate between two groups was significant $(p<0.05)$. The reason for this low continuation rate was mostly failure to follow up followed by removal and expulsion of IUCD.

In the study conducted by Gupta et al the continuation rate of post placental IUCD was $87.3 \%$ and that of interval insertion was $92 \% .{ }^{11}$ Celen et al found the continuation rate of early post partum insertion of IUCD was $87.6 \% .^{12}$ Sevki et al found that the continuation rate of IUCD after 6 months of use was $81.6 \%$ and $62 \%$ after 1 year of use. ${ }^{13}$ O'Henley et al found the lower continuation rates in case of immediate insertion $(65.5 \%)$ as compared to delayed insertion $(71.3 \%)$ after 24 months of follow up. ${ }^{14}$ Tatum et al found the continuation rate of GYNE-T 380 after 6 months of insertion as $80 \% .{ }^{15}$ Chen BA et al found continuation rates in immediate insertion as $84.3 \%$ and that of delayed insertion as $76.5 \%$ after 6 months of insertion of LNG-IUCD. ${ }^{9}$

According to present study, in post placental group $92.7 \%$ of the clients who turned up for follow up were fully satisfied, $4.4 \%$ were partially and $2.9 \%$ were not at all satisfied. In delayed insertion group $81.8 \%$ were fully satisfied, $9.1 \%$ were partially and $9.1 \%$ were totally unsatisfied.

Thus, from present study we came to know that postpartum insertion of PPIUCD is safe, convenient and cost-effective method of contraception. Acceptance of postpartum IUCD is low in general population and the reason could be lack of knowledge and awareness which can be overcome by proper counseling. The acceptance was high in the immediate postpartum group as compared to extended insertion group for the same reason. Continuation rates were also higher in immediate insertion group. Thus, we recommend that the unmet needs of family planning can be addressed by promoting institutional deliveries, so that every eligible couple could be counseled for IUCD insertion in the postpartum period. 


\section{ACKNOWLEDGMENTS}

Authors would like to thank all the clients who trusted and cooperated us in this study.

Funding: No funding sources

Conflict of interest: None declared

Ethical approval: The study was approved by the Institutional Ethics Committee

\section{REFERENCES}

1. Safwat A. Mohamed, Momen A. Kamel, Omar M. Shaaban, Hossam T. Salem. Acceptability for the Use of Postpartum Intrauterine Contraceptive Devices: Assiut Experience. Med Principles Pract. 2003;12:170-5.

2. Long Term Safety and Effectiveness of CopperReleasing Intrauterine Devices; HRP External Evaluation 2003-2007; Outcome, Impact;6,7.

3. United Nations Development Programme, United Nations Population Fund, World Health Organization. Long-term reversible contraception: Twelve years of experience with the TCu380A and TCu220C. Contraception. 1997;56:341-52.

4. Sivin I, Stern J, Diaz S, Pavéz M, Alvarez F, Brache $\mathrm{V}$ et al. Rates and outcomes of planned pregnancy after use of Norplant capsules, Norplant II rods, or levonorgestrel-releasing or copper $\mathrm{TCu} 380 \mathrm{Ag}$ intrauterine contraceptive devices. Am J Obstet Gynecol. 1992;166(4):1208-13.

5. Skjeldestad FE. The impact of intrauterine devices on subsequent fertility. Curr Opin Obstet Gynecol. 2008;20(3):275-80.

6. Gillian D, Bimla SE. Intrauterine contraceptives (IUCs). In Robert AH, James T, Anita NL, Willard C Jr, Deborah K, Michael PS. Contraceptive technology (20th revised ed.). New York: Ardent Media;2011:147-191.

7. Padubidri VG, Daftary SN. Howkins and Bourne Shaws Text Book of Gyanecology. 15th Edition; p18,19 .
8. Ogburn JA, Espey E, Stonehocker J, Barriers to intrauterine device insertion in post partum women. Contraception. 2005;72(6):426-9.

9. Chen BA, Hayes JL, Hohmann HL, Perriera LK, Reeves MF, Creinin MD. A randomized trial of post placental compared to delayed insertion of levonorgestrol releasing intrauterine device after vaginal delivery. Contraception. 2009;80(2):205.

10. Gujju RLB, Prasad U, Prasad U. Study on the acceptance, complications and continuation rate of post-partum family planning using the post placental intrauterine contraceptive device among women delivering at a tertiary care hospital. Int J Reprod Contracept Obstet Gynecol. 2015;4(2):388-391.

11. Gupta A, Verma, Chauhan J. Evaluation of PPIUCD versus interval IUCD (380A) insertion in a teaching hospital of Western U. P. Int J Reprod Contracept Obstet Gynecol. 2013;2(2):204-8.

12. Celen S, Moroy P, Sucak A, Aktulay A, Danisman N. Clinical outcomes of early post placental insertion of intrauterine contraceptive devices. Contraception. 2004;69:279-82.

13. Çelen Ş, Sucak A, Yıldız Y, Danışman N. Immediate postplacental insertion of an intrauterine contraceptive device during cesarean section in Turkey. Contraception. 2011;84:240-3.

14. O'Henley K, Huber DH. Post Partum IUDs; Key for Success; Association for Voluntary Surgical Contraception, New York. Contraception. 1992;45(4):351-61.

15. Tatum HJ, Beltran RS, Ramos R, Van Kets H, Sivin I, Schmidt FH. Immediate postplacental insertion of GYNE-T 380 and GYNE-T 380 postpartum intrauterine contraceptive devices: Randomized study. Am J Obstet Gynecol. 1996;175:1231-5.

Cite this article as: Jain N, Akhtar N. Acceptability, continuation and satisfaction of postpartum intrauterine contraceptive device (PPIUCD) and delayed insertion: a comparative study. Int J Reprod Contracept Obstet Gynecol 2017;6:3540-4. 